\title{
FORMULASI DAN EVALUASI MIKROEMULGEL DARI EKSTRAK DAUN SIRSAK (Annona muricata L.)
}

\author{
Jafar G. ${ }^{1}$, Muhsinin S. ${ }^{1}$, Hayatunnufus A. ${ }^{1}$ \\ ${ }^{1}$ Sekolah Tinggi Teknologi Bandung, Jl.Soekarno Hatta No 754 Cibiru Bandung 40614 \\ garnadi.jafar@stfb.ac.d
}

\begin{abstract}
ABSTRAK
Staphylococcus aureus merupakan salah satu bakteri penyebab jerawat. Salah satu tanaman yang berpotensi sebagai antijerawat adalah daun sirsak. Penelitian ini dilakukan untuk mengembangkan formulasi ekstrak daun sirsak dan evaluasinya, sehingga memiliki stabilitas yang baik. Penelitian ini diawali dengan mengekstraksi daun sirsak menggunakan metode maserasi, kemudian dilakukan fermentasi untuk membandingkan konsentrasi hambat minimum yang lebih efektif sebagai antibakteri Staphyloccoccus aureus. Setelah itu, dibuat 9 formula mikroemulsi dengan variasi konsentrasi dan jenis kosurfaktan yaitu Tegocare $^{\circledR}$ dan Plantacare $^{\circledR}$. Pemilihan formula mikroemulsi terbaik dipilih berdasarkan evaluasi secara organoleptik. Terhadap mikroemulsi terbaik dilakukan karakterisasi lainnya seperti pengujian freeze and thaw, uji sentrifugasi dan uji TEM (Transmission Electron Microscopy). Evaluasi sediaan mikroemulgel meliputi organoleptik, $\mathrm{pH}$, viskositas, homogenitas, dan daya sebar selama penyimpanan 28 hari, serta uji panelis.

Hasil menunjukkan bahwa tidak ada perbedaan signifikan (sig > 0,05) antara ekstrak fermentasi dan nonfermentasi, sehingga ekstrak nonfermentasi digunakan dalam formulasi dengan konsentrasi 10 $\mathrm{mg} / \mathrm{ml}$. Mikroemulsi dengan kosurfaktan Plantacare ${ }^{\circledR} 10 \%$ merupakan formula mikroemulsi terpilih. Pada pengujian freeze and thaw, mikroemulsi stabil sampai siklus kelima, sedangkan pada pengujian TEM mikroemulsi memiliki ukuran partikel sebesar 50,0 nm. Mikroemulsi terpilih diinkorporasi ke dalam 3 formula basis gel $\left(\right.$ Viscolam $\left.^{\circledR}\right)$ dengan variasi konsentrasi $8 \%-10 \%$. Dari hasil analisis menggunakan ANOVA, nilai $\mathrm{pH}$ pada ketiga formula tersebut tidak konstan (sig < 0,05), sedangkan untuk nilai viskositas hanya formula II (konsentrasi 9\%) yang konstan pada nilai sig $>0,05$.
\end{abstract}

Kata Kunci: Daun Sirsak (Annona muricata L.), Antibakteri, Mikroemulgel

\section{ABSTRACT}

Staphylococcus aureus is one of the bacteria that can cause acne. One of the potential crop as antiacne is soursop leaves. This research was conducted to develop and evaluation of formulation soursop leaf extract that has good stability. This research begins by extracting the leaves of the soursop through maceration, fermentation then comparing the minimum inhibitory concentration which one is more effective as an antibacterial against Staphyloccoccus aureus. Afterwards, 9 microemulsion formula with variations in the concentration and type of cosurfactant used Tegocare ${ }^{\circledR}$ and Plantacare ${ }^{\circledR}$ were prepared. Selection of the best microemulsion formula decided by organoleptic evaluation. Microemulsion can be characterized by freeze and thaw, centrifugation and TEM (Transmission Electron Microscopy) tests. Evaluation on microemulgel preparations include organoleptic, pH, viscosity, homogeneity, panelists study and the scattering ability during 28 days of storage.

The results showed that there was no significant difference (sig > 0.05) between fermented and nonfermented extract, so the chosen non-fermented extract into a formulation with a concentration of 10 $\mathrm{mg} / \mathrm{ml}$. Microemulsion with $10 \%$ of Plantacare ${ }^{\circledR}$ cosurfactant was microemulsion formula selected. In freeze and thaw tests, it was proofed that microemulsions were stable until the fifth cycle, while the TEM on microemulsion had a particle size of $50.0 \mathrm{~nm}$. Selected microemulsion was incorporated into gel base formula 3 (Viscolam ${ }^{\circledR}$ ) with various concentrations of $8 \%-10 \%$. The results of the analysis using ANOVA, the $\mathrm{pH}$ value in the third formula was not constant (sig $<0.05)$, while for viscosity values formula II (concentration 9\%) was constant (sig > 0.05).

Keywords: Soursop Leaves (Annona muricata L.), Antibacterial, Microemulgel 


\section{PENDAHULUAN}

Di Indonesia terdapat beragam aktivitas, baik di luar maupun di dalam ruangan. Tanpa disadari, ketika kesehatan kulit kurang diperhatikan dapat berpotensi terpapar oleh mikroorganisme, salah satunya bakteri Staphylococcus aureus (S.aureus). S.aureus ini merupakan bakteri flora normal pada permukaan kulit, namun jika jumlahnya berlebih dapat menyebabkan jerawat (Agyare $e t$ al., 2013). Jerawat yang tumbuh dapat menyebabkan berbagai keluhan seperti rasa gatal, rasa tidak nyaman, dan dapat menyebabkan inflamasi (peradangan) pada kulit, sehingga diperlukan alternatif untuk mengatasinya yaitu menggunakan daun sirsak.

Menurut penelitian Ika et al. (2014) menerangkan bahwa daun sirsak mengandung senyawa aktif seperti tanin, fitosterol, kalsium oksalat, dan alkaloid murisin yang dapat memerangi timbulnya jerawat akibat bakteri S.aureus. Menurut penelitian Ginda et al. (2014) menyatakan bahwa ekstrak daun sirsak mampu menghambat pertumbuhan Staphylococcus aureus pada konsentrasi 150 $\mathrm{mg} / \mathrm{ml}$ dengan zona hambat $14,1 \mathrm{~mm}$.

Berdasarkan hasil penelitian tersebut, perlu dilakukan upaya untuk meningkatkan aktivitas ekstrak daun sirsak yaitu dengan teknik bioteknologi, salah satunya dengan cara fermentasi. Fermentasi ini dilakukan dengan penambahan bakteri asam laktat. Manfaat dari fermentasi ini dapat meningkatkan produksi senyawa kimianya, sehingga diharapkan memiliki efektivitas yang lebih baik. Menurut penelitian yang dilakukan oleh Muizuddin (2015) menyatakan bahwa ekstrak daun sirsak mengalami peningkatan aktivitas terhadap bakteri S.aureus sebesar $40 \%$ selama proses fermentasi.

Sediaan untuk antijerawat banyak dipasarkan dalam sistem penghantaran oral maupun topikal. Pada penelitian ini akan dipilih rute topikal karena dirasa lebih menguntungkan yaitu dapat menghindari efek saluran cerna (first pass metabolism) serta diharapkan dapat berpenetrasi cepat melalui membran kulit menuju targetnya.

Seiring berkembangnya teknologi, daun sirsak ini akan dibuat dalam bentuk sediaan mikroemulsi yang diinkorporasikan ke dalam fasa gel. Mikroemulsi memiliki karakteristik antara lain: jernih, transparan, dan stabil secara termodinamika. Salah satu keuntungan mikroemulsi yang dimanfaatkan adalah ukuran partikelnya yang kecil sehingga membuat luas permukaannya semakin besar dan absorpsinya akan semakin cepat. Namun demikian, mikroemulsi ini memiliki viskositas yang rendah (mudah mengalir). Menurut Santos et al. (2008) sediaan yang memiliki viskositas rendah akan mudah mengalir saat digunakan sehingga pelepasan obat melewati kulit akan terganggu. Menurut Nur Illiyin et al. (2012) menyatakan bahwa viskositas rendah dan waktu kontak sediaan dengan kulit yang singkat menyebabkan jumlah obat yang terabsorpsi ke dalam kulit lebih sedikit. Sehingga diperlukan suatu basis dalam pengaplikasiannya. Salah satu basis yang dapat digunakan adalah gel. Menurut Garnadi et al. (2015) membandingkan SLN ceramide yang diinkorporasikan sediaan gel dan krim. Gel memiliki efek yang lebih baik dibandingkan dengan krim, karena gel memiliki jumlah air yang lebih banyak dan dapat menghidrasi stratum korneum, sehingga dapat menganggu konformasi brick dan mortart, yang menghasilkan penetrasi yang lebih baik. Selain itu gel memiliki konsistensi lebih kecil sehingga lebih mudah menyebar dan pelepasan obatnya baik, serta tingginya hidrasi membran yang dapat memudahkan penetrasi karena sifat permeabilitasnya tinggi, serta penerimaan yang baik pada kulit dengan sensasi dingin dan mudah dicuci oleh air.

Mikroemulsi berbasis gel adalah sediaan kosmetik yang berasal dari mikroemulsi yang terbentuk kemudian diinkorporasikan ke dalam fasa gel. Ekstrak daun sirsak yang akan dibuat dalam bentuk mikroemulsi berbasis gel ini diharapkan menjadi sediaan yang transparan dan rheologi yang baik, memiliki sensasi dingin di kulit, serta pelepasan dan pendistribusian zat aktif yang lebih cepat. Tujuan diformulasikannya mikroemulgel ini diharapkan memiliki stabilitas dan penetrasi yang baik, serta aktivitas antijerawat yang lebih baik setelah dilakukan fermentasi pada bahan aktifnya.

\section{BAHAN DAN METODE}

Tahapan pertama pada penelitian ini adalah pemeriksaan bahan baku dengan memilih simplisia yang didapatkan di Perkebunan Manoko Lembang, Bandung, kemudian dilakukan determinasi untuk mengetahui kebenaran tumbuhan uji yang 
Jafar dkk.

Jurnal Farmasi Udayana, Vol. 6 No. 2, Tahun 2017, 6-14

digunakan. Determinasi tanaman dilakukan dengan cara membandingkan bahan yang akan di determinasi dengan pustaka.

Pembuatan ekstrak daun sirsak (Annona muricata L.) dilakukan dengan metode maserasi yaitu dengan merendam simplisia selama 3x24 jam kemudian dipekatkan dengan rotary evaporator untuk di dapatkan ekstrak kental. Skrining fitokimia dilakukan setelah didapatkan ekstrak kental. Tujuan dilakukan skrining fitokimia untuk mengetahui kandungan senyawa yang terdapat di dalam ekstrak, meliputi pemeriksaan alkaloid, flavonoid, tannin, saponin, steroid/triterpenoid dan fenol. Setelah itu dilakukan proses fermentasi menggunakan bakteri asam laktat, dengan harapan dapat meningkatkan aktivitas antibakterinya dan dilakukan uji aktivitas antibakteri dengan metode cakram kertas.

Tahapan berikutnya dilakukan optimasi pembentukan mikroemulsi agar mengetahui komposisi bahan yang sesuai dan menghasilkan sediaan mikroemulsi yang stabil, menggunakan surfaktan dan beberapa jenis kosurfaktan serta variasi konsentrasinya. Hal yang harus diperhatikan meliputi kecepatan pengadukan pada 500-900 rpm, lama pengadukan 10-30 menit, dan suhu 30-50 ${ }^{\circ} \mathrm{C}$. Dibuat 9 formula dengan 2 jenis kosurfaktan dan variasi konsentrasinya adalah 2-5\% dan 5\% - 25\%, serta dipilih formula terbaik. Pada formula terpilih ditambahkan ekstrak untuk mencari formula yang optimum. Selanjutnya dilakukan

\section{HASIL}

\section{Pembentukan Mikroemulsi Blanko}

Tabel 1. Komposisi Bahan Untuk Optimasi Mikroemulsi dengan Variasi Konsentrasi Kosurfaktan $\left(\right.$ Plantacare ${ }^{\circledR}$ )

\begin{tabular}{|c|c|c|c|c|c|c|c|c|c|}
\hline \multirow[t]{2}{*}{ Bahan } & \multicolumn{9}{|c|}{ Formula $(\%$ b/v) } \\
\hline & F1 & $\mathrm{F} 2$ & F3 & F4 & F5 & F6 & F7 & F8 & F9 \\
\hline $\begin{array}{l}\text { Tegocare }^{\circledR} \text { (polyglyseril-3 methyl } \\
\text { glukosa distearat) }\end{array}$ & 2 & 2,5 & 3 & 4,5 & 5 & - & - & - & - \\
\hline Plantacare $^{\circledR}$ (lauryl glikosida) & - & - & - & - & - & 5 & 10 & 15 & 20 \\
\hline $\begin{array}{l}\text { Tween } \\
\text { sorbitan) }\end{array}$ & 35 & 35 & 35 & 35 & 35 & 35 & 35 & 35 & 35 \\
\hline Minyak Zaitun & 3 & 3 & 3 & 3 & 3 & 3 & 3 & 3 & 3 \\
\hline Aquadeion ad (mL) & 100 & 100 & 100 & 100 & 100 & 100 & 100 & 100 & 100 \\
\hline
\end{tabular}

Tahap pertama yang dilakukan adalah optimasi formula mikroemulsi menggunakan satu jenis surfaktan $\left(\right.$ Tween $80^{\circledR}$ ) dengan variasi jenis dan konsentrasi kosurfaktan (Plantacare ${ }^{\circledR}$ dan Tegocare $\left.^{\circledR}\right)$. Tujuan dari optimasi formula adalah untuk menentukan formula terpilih berdasarkan hasil evaluasi secara organoleptik. Hal yang mempengaruhi pembentukan karakterisasi sifat fisik, $\mathrm{pH}$, freeze and thaw, sentrifugasi, serta morfologinya yang meliputi bentuk dan ukuran globul menggunakan Transmission Electron Microscope (TEM) yang akan dilakukan di Universitas Gadjah Mada, Yogyakarta.

Tahapan berikutnya dibuat fasa gel dengan memvariasikan beberapa konsentrasi basis gel golongan akrilat kopolimer dengan bahan tambahan lain yang diperlukan dalam pembentukan gel. Variasi konsentrasinya yaitu $3 \%$ - 9\%, serta dipilih 3 formula terpilih. Setelah didapatkan formula basis gel terpilih, dilakukan evaluasi untuk mengetahui kualitas gel. Evaluasi yang dilakukan adalah pengamatan secara organoleptik, pengukuran $\mathrm{pH}$ dan viskositas.

Tahapan terakhir setelah semua fasa dibentuk, mikroemulsi yang mengandung ekstrak daun sirsak diinkorporasikan ke dalam masing-masing formula gel sampai terbentuk mikroemulgel. Formulasi mikroemulgel terbaik dilakukan karakterisasi yang meliputi pengamatan organoleptik, pengukuran $\mathrm{pH}$, pengukuran viskositas, uji homogenitas, uji daya sebar, uji hedonik, serta uji stabilitas yang dilakukan selama 28 hari. Selanjutnya dilakukan pengolahan data menggunakan metode ANOVA. 
Jafar dkk.

Jurnal Farmasi Udayana, Vol. 6 No. 2, Tahun 2017, 6-14

yang jernih dan encer pada konsentrasi $2 \%$; $2,5 \%$; 3\%; dan $4,5 \%$ dengan kecepatan sedangkan pada konsentrasi 3\% dan 4,5\% pengadukan 500, 700, dan $900 \mathrm{rpm}$ pada suhu mengalami kekeruhan (opaque).

$50{ }^{\circ} \mathrm{C}$ selama 20 menit. Setelah beberapa hari, mikroemulsi yang terbentuk tidak stabil, pada konsentrasi $2 \%$ dan 2,5\% mengalami rigiditas,

\begin{tabular}{cc} 
Karakterisasi Mikroemulsi Ekstrak Daun Sirsak \\
Tabel 2. Komposisi Formulasi Mikroemulsi Terpilih \\
\hline Bahan & Formula (\% b/v) \\
\hline Ekstrak Daun Sirsak $^{\circledR}$ & $3 \times$ dosis \\
Plantacare $^{\circledR}$ & 10 \\
Tween 80 $^{\circledR}$ & 35 \\
Minyak Zaitun & 3 \\
Aquadeion ad & $100 \mathrm{~mL}$ \\
\hline
\end{tabular}

Mikroemulsi ekstrak daun sirsak dikarakterisasi dengan mengamati secara organoleptik pada suhu ruang, uji sentrifugasi, dan stabilitas dipercepat (Freeze and Thaw) selama lima siklus. Pengujian sentrifugasi dilakukan untuk mengetahui pengaruh gravitasi

terhadap kestabilan mikroemulgel (Dewi, 2015). Hasil uji sentrifugasi menunjukkan bahwa mikroemulsi tetap stabil. Hasil pengujian Freeze and Thaw menunjukkan mikroemulsi ekstrak daun sirsak stabil sampai siklus kelima, dengan parameter tidak terdapat perubahan pada warna, aroma, transparansi dan homogenitas.

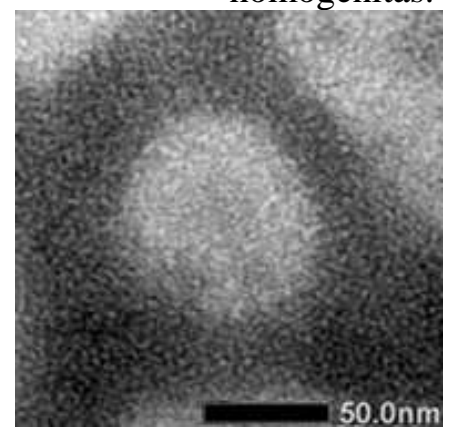

Gambar 1. Hasil uji ukuran partikel menggunakan TEM dengan 80.000x perbesaran

Pembentukkan Mikroemulgel Ekstrak Daun Sirsak

Tabel 3. Komposisi Mikroemulgel dengan Mikoemulsi dan Basis Gel Terpilih

\begin{tabular}{|c|c|c|c|}
\hline \multirow[t]{2}{*}{ Bahan } & \multicolumn{3}{|c|}{ Formula $(\%$ b/v) } \\
\hline & FT1 & FT2 & FT3 \\
\hline $\begin{array}{l}\text { Mikroemulsi Ekstrak Daun } \\
\text { Sirsak (ml) }\end{array}$ & 33,33 & 33,33 & 33,33 \\
\hline Viscolam $^{\circledR}$ & 8 & 9 & 10 \\
\hline Propilenglikol & 15 & 15 & 15 \\
\hline Gliserin & 5 & 5 & 5 \\
\hline Microcare $^{\circledR}$ & 0,3 & 0,3 & 0,3 \\
\hline TEA & 21 & 23 & 25 \\
\hline Aquadeion ad & $\begin{array}{l}100 \\
\mathrm{~mL}\end{array}$ & $\begin{array}{l}100 \\
\mathrm{~mL}\end{array}$ & $\begin{array}{l}100 \\
\mathrm{~mL}\end{array}$ \\
\hline
\end{tabular}


Jafar dkk.

Jurnal Farmasi Udayana, Vol. 6 No. 2, Tahun 2017, 6-14

\section{Evaluasi Mikroemulgel}

1. Uji Organoleptik

Tabel 4. Hasil Pengamatan Organoleptik

\begin{tabular}{ccccccccc}
\hline \multirow{2}{*}{ Formula } & Parameter & \multicolumn{7}{c}{ Perubahan Organoleptik Sediaan Mikroemulgel pada hari } \\
& & & \multicolumn{7}{c}{ ke- } \\
\cline { 3 - 8 } & WT I & H1 & H3 & H5 & H7 & H14 & H21 & H28 \\
& & - & - & - & - & - & - & - \\
& Aroma & - & - & - & - & - & - & - \\
& Transparansi & - & - & - & - & - & - & - \\
& Homogenitas & - & - & - & - & - & - & - \\
\hline \multirow{2}{*}{ FT II } & Warna & - & - & - & - & + & + & + \\
& Aroma & - & - & - & - & - & - & - \\
& Transparansi & - & - & - & - & - & - & - \\
& Homogenitas & - & - & - & - & - & - & - \\
\hline \multirow{2}{*}{ FT III } & Warna & - & - & - & - & + & + & + \\
& Aroma & - & - & - & - & - & - & - \\
& Transparansi & - & - & - & - & - & - & - \\
& Homogenitas & - & - & - & - & - & - & - \\
\hline
\end{tabular}

Ket :

(+) Ada Perubahan ; (-) Tidak ada Perubahan

Pada percobaan diperoleh hasil organoleptik pada suhu ruang, tidak terjadi perubahan aroma, transparansi serta homogenitas dari sediaan mikroemulgel, sedangkan pada warna secara fisik untuk FT II dan FT III mengalami perubahan menjadi lebih keruh pada hari ke 14, namun ketika diamati diatas lampu LED, ketiga sediaan mikroemulgel tetap transparan. Hal ini menunjukkan bahwa FT II dan FT III tidak stabil karena ketidakmampuan sediaan dalam mempertahankan sifat fisiknya.

2. Pengukuran $\mathrm{pH}$

Pada hari ke-1, nilai pH untuk FT I, FT II dan FT III berturut-turut yaitu $6,80 \pm 0,03 ; 6,75$ $\pm 0,02 ; 6,72 \pm 0,02$. Setelah penyimpanan 28 hari masing-masing formula menunjukkan nilai $\mathrm{pH}$ secara berturut-turut $6,64 \pm 0,03 ; 6,56 \pm$ 0,$02 ; 6,58 \pm 0,02$.

Grafik perbandingan nilai $\mathrm{pH}$ dapat dilihat pada Gambar 2 berikut.

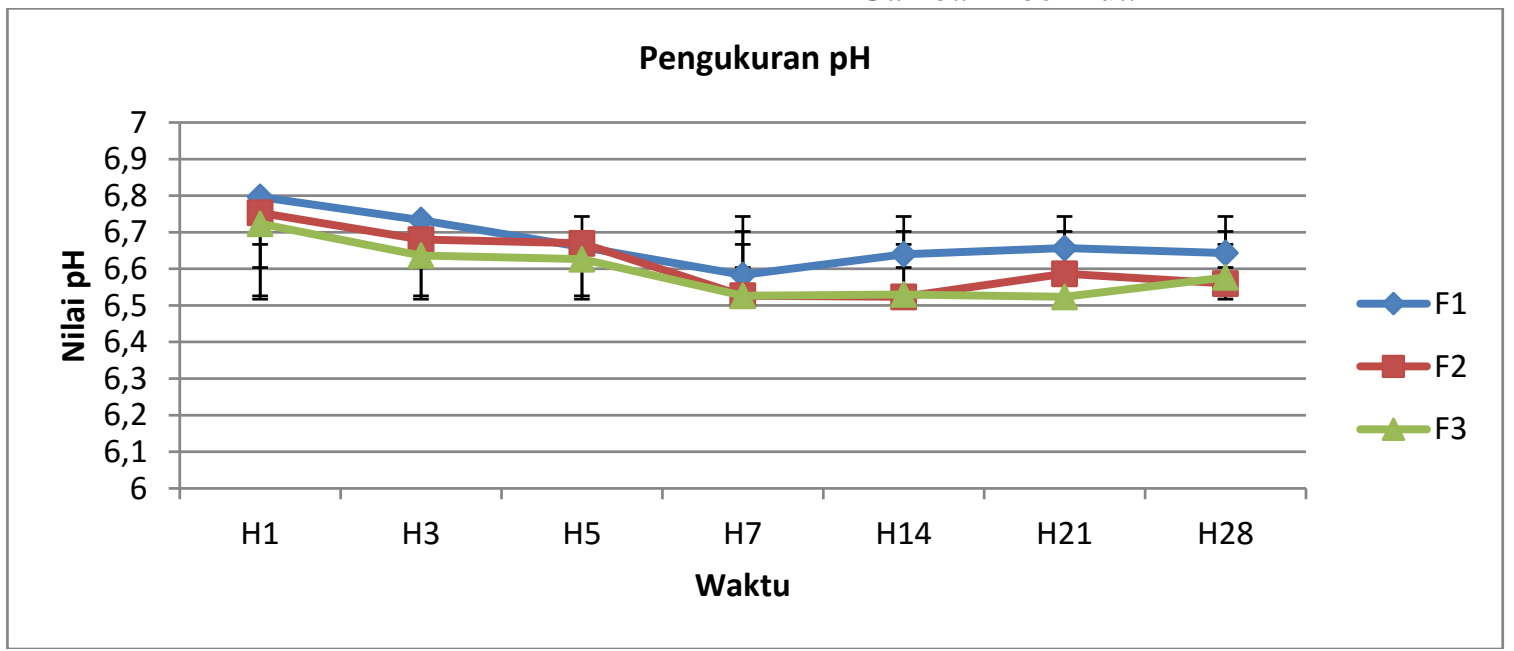

Gambar 2. Grafik hasil pengukuran nilai pH mikroemulgel pada suhu ruang

\section{Pengukuran Viskositas}

Hasil percobaan menunjukkan semakin tinggi konsentrasi Viscolam ${ }^{\circledR}$, maka akan semakin tinggi pula viskositasnya.
Grafik perbandingan nilai viskositas dapat dilihat pada Gambar 3 berikut. 
Jafar dkk.

Jurnal Farmasi Udayana, Vol. 6 No. 2, Tahun 2017, 6-14

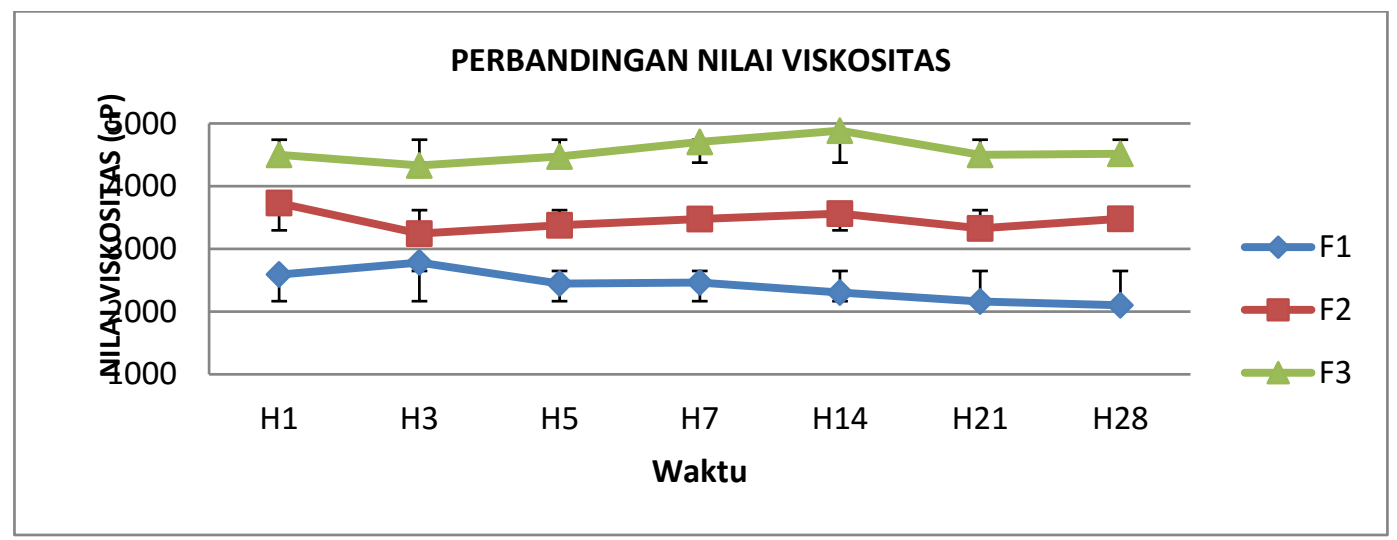

Gambar 3. Grafik hasil pengukuran nilai viskositas mikroemulgel pada suhu ruang

\section{Uji Homogenitas}

Uji homogenitas dilakukan untuk mengetahui kehomogenan dari sediaan mikroemulgel. Homogenitas ditunjukkan dengan tidak adanya butiran kasar pada objek glass (Ditjen POM, 2000). Berdasarkan hasil pengujian pada ketiga formula tersebut, tidak terdapat butiran kasar yang menggumpal, sehingga ketiga formula tersebut dapat dikatakan homogeny

5. Uji Panelis

a. Uji Kesukaan
Berdasarkan parameter hedonik dari rentang satu sampai lima, dapat diketahui bahwa rata-rata panelis menyukai warna dan kenyamanan dari FT I, II, dan III, sedangkan untuk parameter aroma, rata-rata panelis agak menyukainya. Secara keseluruhan score ratarata untuk FT I, II, dan III berturut-turut adalah 3,25; 3,1 dan 3,22. Hasil menunjukkan bahwa panelis cenderung menyukai FT I. Perbandingan hasil uji kesukaan dapat dilihat pada grafik 4 berikut.

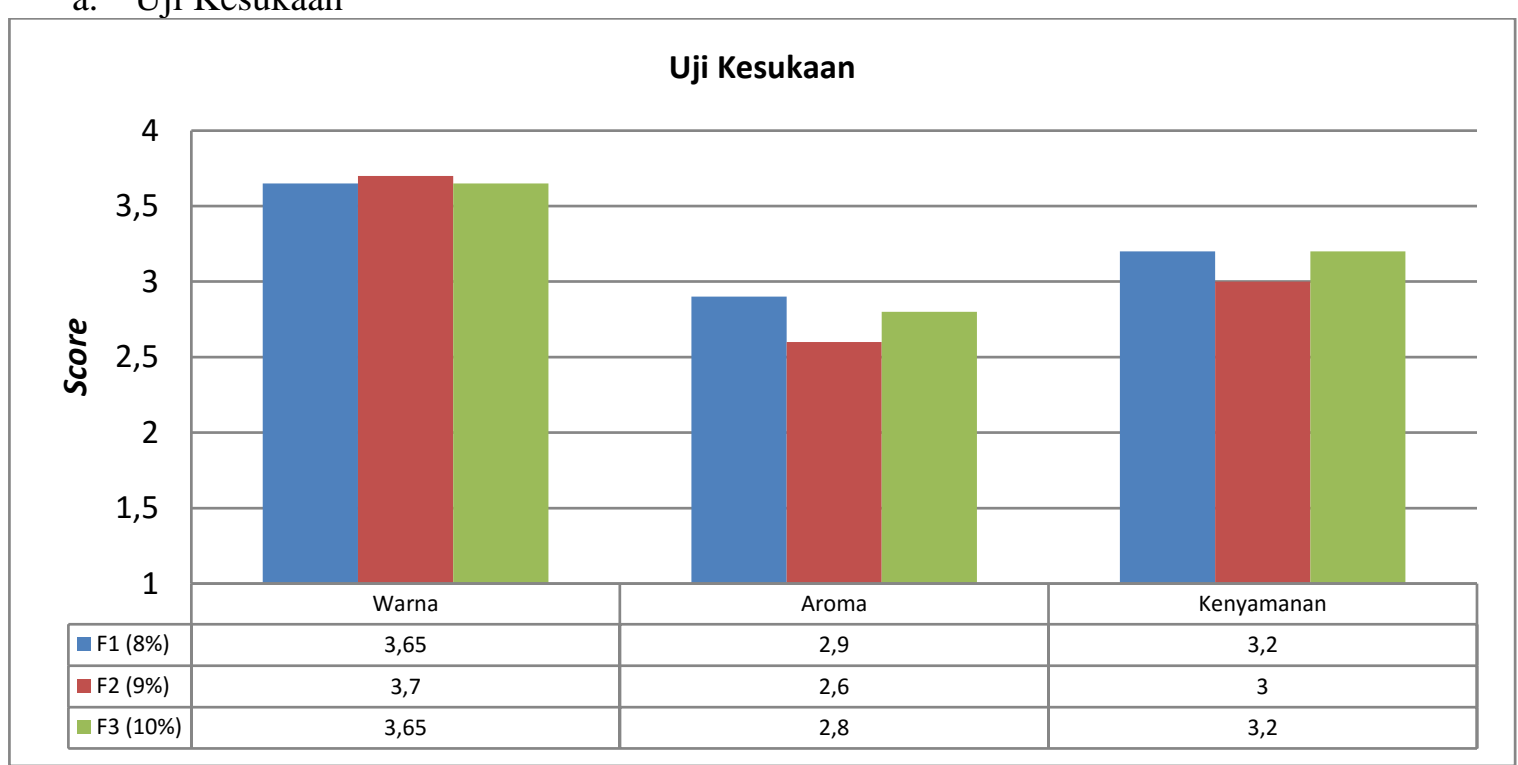

Gambar 4. Grafik hasil uji kesukaan

b. Uji Iritasi dan Keamanan

Berdasarkan parameter hedonik dari rentang satu sampai lima, dapat diketahui bahwa rata-rata sediaan tidak menimbulkan reaksi iritasi dan sensasi gatal pada panelis, sedangkan rata-rata panelis cenderung timbul sensasi dingin dan kelengketan untuk FT I, II dan III. Perbandingan hasil uji iritasi dan kenyamanan dapat dilihat pada grafik 5 berikut. 
Jafar dkk.

Jurnal Farmasi Udayana, Vol. 6 No. 2, Tahun 2017, 6-14

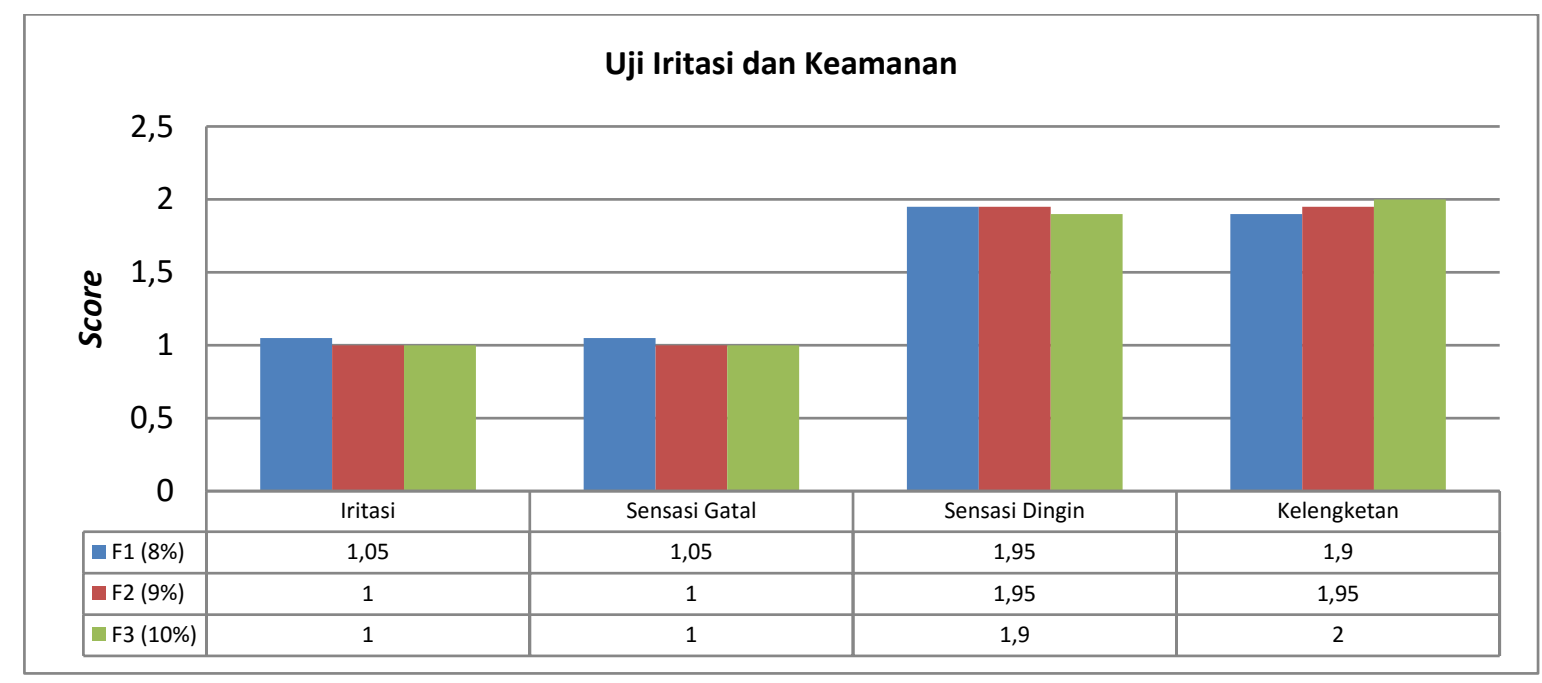

Gambar 5. Grafik hasil uji iritasi dan keamanan

\section{PEMBAHASAN}

Berdasarkan hasil evaluasi organoleptik, formula dengan menggunakan Plantacare ${ }^{\circledR} 10 \%$ merupakan konsentrasi optimum yang menghasilkan mikroemulsi yang baik, memiliki konsistensi pada kejernihan dan rheologi yang rendah dibandingkan dengan formula lainnya. Pada dasarnya Plantacare ${ }^{\circledR}$ berbentuk semi solid sehingga tidak menyebabkan rigiditas. Oleh karena itu, dari hasil optimasi tersebut Plantacare ${ }^{\circledR}$ lebih baik dibandingkan dengan Tegocare $^{\circledR}$ dalam pembentukan mikroemulsi, serta formula terpilih mikroemulsi adalah formula dengan konsentrasi Plantacare ${ }^{\circledR}$ sebesar $10 \%$.

Formulasi yang stabil dan jernih dilakukan pengukuran morfologi berupa bentuk dan ukuran globulnya menggunakan alat TEM (Transmission Electron Microscope) di Jurusan Kimia MIPA Universitas Gadjah Mada. Hasil menunjukkan bahwa mikroemulsi memiliki diameter globul berukuran nanometer yaitu sebesar $50 \mathrm{~nm}$ serta bentuk partikel yang mendekati sferis (Gambar 1). Menurut Fauzy (2012) ukuran globul nanometer yaitu 10-100 nm. Hasil menunjukan bahwa partikel mikroemulsi terdispersi dalam fasa non polar, yaitu larut dalam fase minyak dengan pembawa air (tipe minyak dalam air).

Berdasarkan hasil pengamatan organoleptik, $\mathrm{pH}$, dan viskositas yang dilakukan selama tujuh hari, didapatkan tiga formula terpilih yaitu pada konsentrasi $6 \%, 7 \%$, dan $8 \%$ untuk dijadikan basis gel. Tahapan pembentukan mikroemulgel ekstrak daun sirsak yaitu dengan menambahkan mikroemulsi ekstrak daun sirsak yang terbentuk kedalam basis gel. Setelah penambahan mikroemulsi ekstrak daun sirsak, terjadi perubahan nilai $\mathrm{pH}$ dan viskositas. Viskositas yang hasilkan pada konsentrasi tersebut mengalami penurunan yang membuat sediaan menjadi lebih encer, sehingga dilakukan peningkatan konsentrasi basis gel menjadi $8 \%, 9 \%$, dan $10 \%$, karena ketiga formula tersebut memiliki nilai $\mathrm{pH}$ dan viskositas yang baik.

Ketiga formula mengalami penurunan nilai pH. Menurut Fauzy (2012), hal ini dapat dikarenakan sediaan mengalami hidrolisis dan terjadinya pelepasan ion sehingga $\mathrm{pH}$ menjadi asam. Selain itu penurunan $\mathrm{pH}$ juga dapat disebabkan karena adanya pengaruh $\mathrm{CO}_{2}$ yang bereaksi dengan air di dalam fasa gel,sehingga membentuk asam bikarbonat $\left(\mathrm{H}_{2} \mathrm{CO}_{3}\right)$. Semakin banyak $\mathrm{CO}_{2}$ yang berikatan dengan air, maka akan semakin banyak asam yang terbetuk, sehingga nilai $\mathrm{pH}$ sediaan menjadi turun (Dzuhro, 2014). Berdasarkan analisis $\mathrm{pH}$ menggunakan metode statistik Analysis of Varians (ANOVA) menunjukkan bahwa terdapat perbedaan signifikan pada ketiga formula yang ditandai dengan nilai sig $=0,004$ ( $\operatorname{sig}<0,05)$. Pada FT I (sig = 0,000), FT II (sig $=0,000)$, dan FT III (sig $=0,000)$ terdapat perbedaan yang sangat signifikan $($ sig $<0,05)$ pada masa penyimpanan selama 28 hari pada suhu ruang (Lampiran 14 dan 15). Ketiga formula mikroemulgel tersebut dinyatakan tidak stabil secara kimia. Hal tersebut diduga karena adanya interaksi dengan wadah atau bahan-bahan lain, serta adanya reaksi kimia yang berarti. Berdasarkan standar SNI 16-43991996, nilai $\mathrm{pH}$ pada ketiga formula tersebut masuk kedalam rentang nilai $\mathrm{pH}$ yang 
dianjurkan untuk sediaan topikal yaitu 4,5 - 8,0 (Dewi, 2010).

Semakin meningkatnya konsentrasi Viscolam $^{\circledR}$ maka viskositas semakin meningkat. Hal ini terjadi karena pada konsentrasi yang lebih tinggi memiliki jumlah gugus karboksilat yang lebih banyak, sehingga semakin banyak pula gugus yang berikatan. Hal ini menyebabkan bobot molekulnya bertambah, sehingga gaya geseknya meningkat dan kecepatan gesernya menurun dan menyebabkan viskositasnya semakin tinggi. (Martin. 1993).

Berdasarkan analisis viskositas menggunakan ANOVA menunjukkan bahwa terdapat perbedaan yang sangat signifikan pada ketiga formula yang ditandai dengan nilai sig $=$ 0,000 (sig < 0,05). Pada FT I (sig = 0,029) dan FT III (sig $=0,043$ ) menunjukkan adanya perbedaan yang signifikan (sig < 0,05), sedangkan FT II $($ sig $=0,123)$ tidak menunjukan perbedaan nilai viskositas yang signifikan (sig $>0,05$ ), sehingga dapat dikatakan bahwa nilai viskositas FT II stabil pada penyimpanan suhu ruang selama 28 hari.

Dari uji homogenitas diketahui tidak terdapatnya butiran-butiran kasar yang menggumpal. Hal ini menunjukkan bahwa formula yang terkandung di dalam gel dapat terlarut dan bercampur dengan baik (Iskandarsyah et al, 2014).

Pengujian daya sebar dilakukan untuk mengetahui seberapa besar penyebaran mikroemulgel ketika diberikan beban. Sediaan yang baik membutuhkan waktu dan beban yang relatif lebih kecil untuk menyebar dan memiliki tingkat penyebaran yang luas (Garg et al, 2010).

\section{KESIMPULAN}

Berdasarkan hasil penelitian pada penyimpanan suhu ruang, mikroemulgel ekstrak daun sirsak dengan konsentrasi basis gel akrilat kopolimer $\left(\right.$ Viscolam $\left.^{\circledR}\right)$ 8\% stabil secara organoleptik, ditandai dengan tidak adanya perubahan pada warna, aroma, transparansi dan homogenitas pada penyimpanan selama 28 hari. Berdasarkan hasil analisis menggunakan ANOVA, ketiga formula menunjukkan adanya perbedaan yang sangat signifikan (sig < 0,05) pada nilai $\mathrm{pH}$, sehingga dapat dikatakan ketiga formula tersebut tidak konstan, tetapi masih dalam rentang $\mathrm{pH}$ sediaan topikal. Pada nilai viskositas, hanya FT II yang dapat dikatakan konstan, karena memiliki nilai sig $=0,123$ (sig $>0,05)$.

\section{DAFTAR PUSTAKA}

Akib Nur Illiyin, Latifah Rahman, dan Marianti A. (2012): Uji Permeasi In Vitro Gel Etosom Vitamin C. Makassar : Universitas Hasanuddin.

Budiputra, Dewa Ken. (2013): Pengembangan Formula dan Karakterisasi Nanoemulsi dan Nanosuspensi Kurkumin Dalam Bentuk Gel Untuk Rute Transdermal. Skripsi, Bandung: Institut Teknologi Bandung.

Dewi, Retno Kemala. (2010): Optimasi Formulasi Mikroemulsi Sediaan Hormon Testosteron Undekanoat. Skripsi. Jakarta: Universitas Islam Negeri Syarif Hidayatullah.

Dewi Yolan Nursintia, Mulyanti Dina, Maulana Indra.T. (2015): Optimasi Formulasi Basis Sediaan Emulgel dengan Variasi Konsentrasi Surfaktan. Bandung: Unisba.

Elvira Putri Ainaro, Amila Gadri, Sani Ega Priani. (2015): Formulasi Sediaan Masker Gel Peel-off Mengandung Lendir Bekicot (Archatina Fulica Bowdich) Sebagai Pelembab Kulit. Fakultas MIPA Unisba.

Fauzy, Aprillia. (2012): Pengaruh Konsentrasi Minyak Ikan Terhadap Penetrasi Kurkumin Dalam Sediaan Mikroemulsi Gel. Skripsi, Depok: Universitas Indonesia.

Garnadi Jafar, Darijanto Sasanti Tarini, Mauludin Rachmat. (2015): Formulasi Solid Lipid Nanoparticle Ceramide. Bandung: Sekolah Tinggi Farmasi Bandung. 87-92.

Hambali Rahmawati M, Dirayah R Husain, Gemini Alam. (2014): Bioaktivitas Metanol Daun Tua Sirsak Annona muricata L. Sebagai Antibakteri Terhadap Staphylococcus aureus dan Propionibacterium acnes. Jurusan Biologi : Universitas Hasanuddin Makasar

Lachman Leon, Herbert A. Lieberman dan Joseph L. Kanig. (1994): Teori dan Praktek Farmasi Industri II. Edisi III. Penerjemah Siti Suyatmi. Jakarta: UI Press; 1076-1079.

Martin Alfred, Swarrick James, Arthur Cammarata. (1993): Farmasi Fisik. Edisi ketiga. 
Jafar dkk.

Jurnal Farmasi Udayana, Vol. 6 No. 2, Tahun 2017, 6-14

Rusmiyati Ika, Dirayah R Husain, Gemini Alam. (2014): Bioaktivitas Ekstrak Metanol Daun Muda Sirsak Annona muricata L. Sebagai Antibakteri Terhadap Staphylococcus aureus dan Propionibacterium acnes. Penelitian, Jurusan Biologi Fakultas Matematika dan Ilmu Pengetahuan Alam : Universitas Hasanuddin Makassar.

Santos AC Watkinson, J Hadgraft, dan M E Lane. (2008): Application of Microemulsions in Dermal and Transdermal Drug Delivery. Skin Pharmacology Physiology, 21, pp 246259.

Soliman S.M, Malak N.S.A, El-Gazayerly O.N, dan Rehim A.A.A. (2010): Formulation of Miecroemulsion Gel System For Transdermal Delivery of Celecoxib: In Vitro Permeation, Antiinflamatory Activity And Skin Irritation Tests. Drug Discoveries \& Therapeutic. 4(6): 459471.

Stanbury.P.F, Whitaker.A, Hall.S.J. (1995): Principles of Fermentation Technology. Edisi Kedua. London: Elsevier's Science and Technology Rights Departement in Oxford; 9-10.

Swarbrick, James dan James C. Boylan. Encyclopedia of Pharmaceutical Technology. New York: Marcel Dekker, Inc. 1994;375, 394. 